\title{
Deep Second Degree Chemical Burn due to Topical Application of Clematis terniflora: A Case Report
}

\author{
Young Woong Mo, Dong Lark Lee, Hea Kyeong Shin, Gyu Yong Jung \\ Department of Plastic and Reconstructive Surgery, Dongguk University College of Medicine, Gyeongju, Korea
}

\begin{abstract}
Clematis terniflora, a member of Ranunculaceae family, is generally used for local treatment of joint pain, burns, lacerations, and warts among the population as a traditional East Asian medicine. But its side effects like contact dermatitis and chemical burn due to topical application of $C$. terniflora should not be overlooked. As a chemical burn due to local application of $C$. terniflora has never been reported in Korea up to date, we are going to present a deep second-degree burn case owing to C. terniflora. A 49-year-old woman was admitted to Dongguk University Hospital because of an open wound on her foot dorsum. The patient suffered from itching sensation when she got a tick bite on the right foot. She applied mashed leaves of $C$. terniflora topically on the tick bite lesion about 4 hours. Four hours later, the patient felt painful tingling sensation with multiple bulla formation. So, she ripped off mashed $C$. terniflora immediately and washed exposed skin, then came to our hospital. We performed bullotomy and foam dressing for 3 days after admission. Three days later, we performed dressing with cultured allogenic keratinocyte (KaloDerm). Surgical procedure was not performed.
\end{abstract}

Keywords: Burns; Burns, chemical; Clematis terniflora

\section{서 론}

으아리풀은 미나리아재비목 미나리아재비과(Ranunculaceae)의 덩굴성 여러해살이풀로 정식 학명은 Clematis terniflora이다. 미나리아재비과에 속하는 여러 식물들은 동아시아지역, 특히 한국과 중국에서 민간요법의 약재로 많이 사용되며, 햇빛이 잘 드는 숲에서 비교적 어렵지 않 게 마주할 수 있다[1,2]. 민간요법으로 뿌리가 천식이나 각기병 치료에 사용되어 왔으며, 이뇨 작 용과 진통 효과가 있는 것으로 알려져 있다[3]. 또한, 풀이나 꽃잎은 국소도포를 통하여 관절염, 건선, 기타 피부질환의 치료에도 쓰인다[2]. 이렇듯 미나리아재비과의 풀은 다양한 약효를 가지 고 있는 반면, 잘못된 방법으로 사용한다면 여러 가지 부작용을 일으킬 수 있다. 특히, 미나리아 재비과의 풀이나 꽃을 피부에 잘못된 방법으로 도포할 경우에는 접촉성 피부염이나 화학 화 상을 유발할 수 있으니 주의해야 한다. 하지만 미나리아재비과 중 으아리풀에 기인한 화학 화 상은 아직 보고된 바 없기에 저자들은 으아리풀의 국소 도포에 기인한 심재성 2도 화상 증례를 보고하고자 한다.

\section{증 례}

49세 여자환자가 우측 발등의 통증을 동반한 수포성 병변으로 동국대학교병원 성형외과 외래 로 내원하였다. 환자는 내원 3 일 전 우측 발등에 피부 병변이 없는 간지러움 증을 느꼈다. 환자 는 벌레 물림에 기인한 것이라 추정하여 민간요법에 따라 밭에서 으아리풀을 구하여 이를 으깨 었다. 이후 으아리풀의 즙을 내어 얇은 천에 적셔 우측 발등의 간지러운 부위에 도포하였다. 환 자는 정확한 도포 방법 및 시간에 대한 정보가 없었기 때문에, 이를 장시간 방치하였다고 한다. 결국 4 시간 정도 지난 후에 우측 발등에 극심한 통증이 있어 도포하였던 얇은 천을 제거하였더

\begin{tabular}{l}
$\quad$ Case Report \\
\hline Received: January 25, 2019 \\
Revised: February 17, 2019 \\
Accepted: February 18, 2019 \\
Corresponding author: \\
Dong Lark Lee, M.D \\
Department of Plastic and Reconstructive \\
Surgery, Dongguk University College of \\
Medicine, 87 Dongdae-ro, Gyeongju 38067, \\
Korea \\
Tel: +82-54-770-1460 \\
Fax: +82-54-770-1469 \\
E-mail: drleedr@gmail.com
\end{tabular}

This is an Open Access article distributed under the terms of the Creative Commons Attribution Non-Commercial License (http://creativecommons.org/licenses/by-nc/4.0/) which permits unrestricted non-commercial use, distribution, and reproduction in any medium, provided the original work is properly cited.

C 2019 Korean Wound Management Society 
니 통증과 함께 홍반, 다발성 수포성 병변이 발생하였다(Fig. 1). 이후 약 이틀 정도 화상 연고(실마진)로 자가 치료하던 중, 병변이 악화되어 수상 후 3 일에 본원 성형외과 외래로 내원하였다. 본원 내원 당시, 우 측 발등에 $15 \times 8 \mathrm{~cm}^{2}$ 크기의 물집이 생겨 있었고, 삼출액은 환자 본인 이 내원 전에 대부분 제거한 상태였다(Fig. 2). 우리는 남아 있는 삼출 물을 제거하였고, 병변에 여전히 실마진 연고와 작은 이물들이 묻어 있어 생리 식염수로 여러 차례 세척하였다. 물집을 일부 제거하여 병 변 바닥을 관찰하였다. 감염의 소견은 없었으나, 진피층의 색이 다소 창백하여 화상 병변의 악화를 우려하여 입원 치료를 결정하였다.

입원 후 삼출물의 양을 감시하여 폼 드레싱과 함께 환부를 높게 유 지, 순환을 원활하게 하였다. 수상 후 7일에 가피 생성이나 감염의 소 견은 없었으나 진피색이 창백하며 상피화가 전혀 진행되지 않아, 심 재성 2도 화상으로 판단하였고 물집을 다 제거한 이후에, 동종유래 표피세포(KaloDerm, Tegoscience, Seoul, Korea)를 적용한 드레싱을 시행하였다. 여전히 삼출물이 다소 나오는 상태였기 때문에, KaloDerm은 유지한 상태로 덮고, 있는 폼은 이틀에 한 번 교체해 주었다.

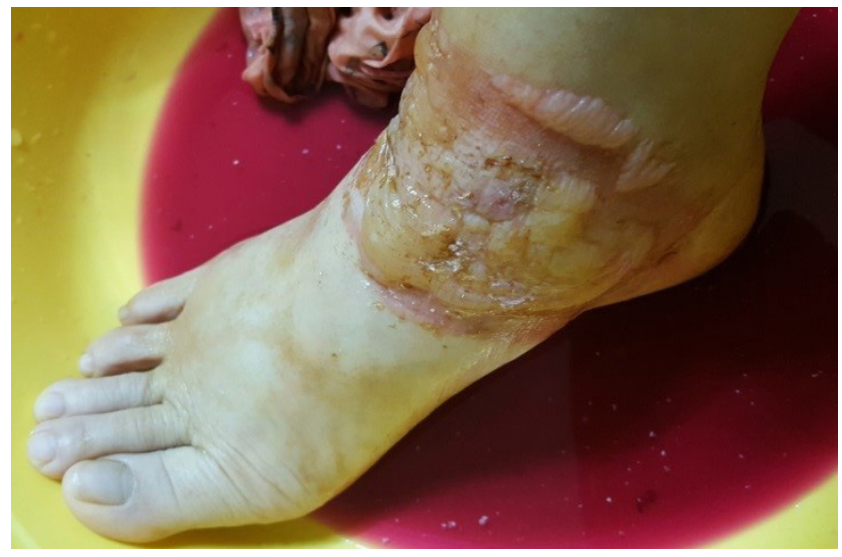

Fig. 1. Clinical photograph on the day of injury. Multiple bulla formed with pain on the dorsum of right foot.

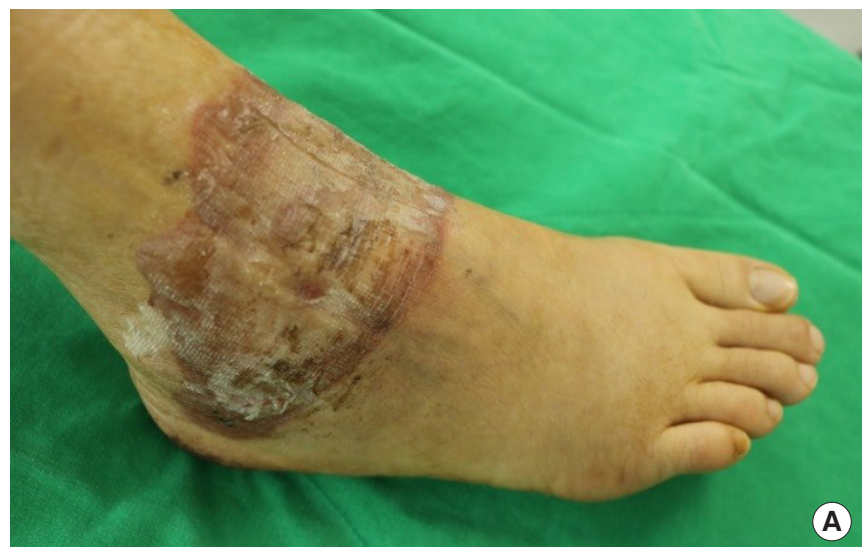

수상 후 9일부터 삼출물 분비가 감소하여 퇴원하여 외래 통원 치료 를 시행하였다. 수상 후 12 일에 KaloDerm을 제거하였고, 수상 후 16 일에는 약 $60 \%$ 정도 상피화가 진행되었으며 남은 부위도 연분홍색으 로 회복 과정에 있었다(Fig. 3). 수상 후 3주에 창상 치유가 완료되었다 (Fig. 4). 환자 증례에 대한 창상 사진 사용에 대하여 환자에게 서면 동 의서를 받았으며, 이 증례 보고에 관련된 IRB 승인을 동국대학교병원 IRB 위원회에서 획득하였다.

\section{고 찰}

으아리풀은 여러해살이 덩굴식물로, 줄기는 자색을 띠고 꽃은 백색 이다(Fig. 5). 한반도 전반에 걸쳐 계곡과 하천 변 풀밭, 농촌 산기슭과 경작지 언저리에 분포해 있다. 으아리풀이라는 이름의 유래를 살펴보 면 으아리풀의 특징을 유추해 볼 수 있다. 미나리아재비과의 식물 대 부분은 독이 있어 야생동물이나 가축들은 뜯어먹지 않는데 으아리 풀도 마찬가지이다. 즉, 으아리는 맛이 맵고 아리기 때문에, 혹은 독성

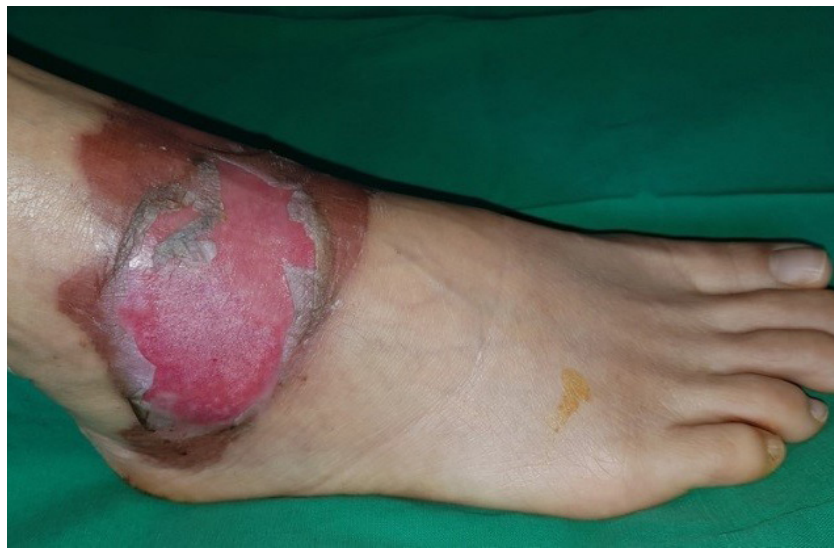

Fig. 3. Clinical photograph 16 days after injury. About $60 \%$ of the wound was epithelized, and the remain of the wound was recovering with light pinkish dermal color.

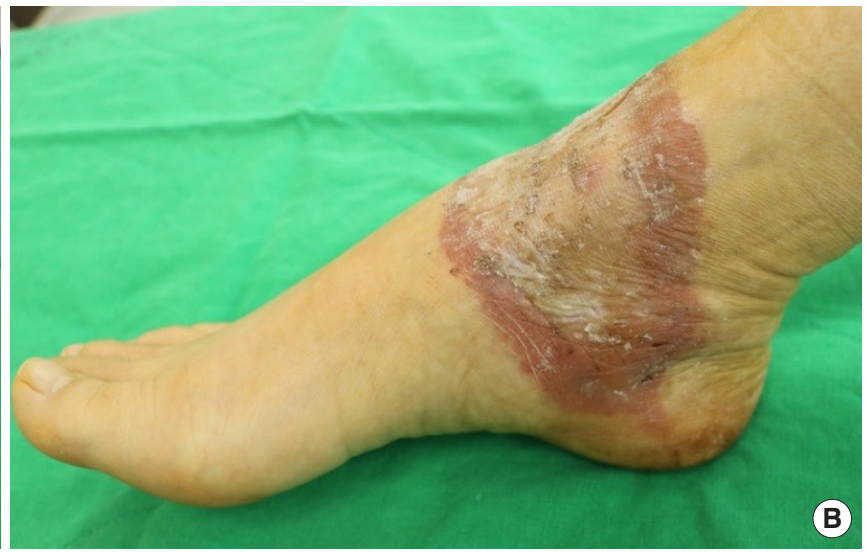

Fig. 2. Clinical photograph 3 days after injury. (A, B) Note the $15 \times 8 \mathrm{~cm}^{2}$ sized bullae on right dorsum of foot. Discharge from the wound has almost been removed by patient herself. 

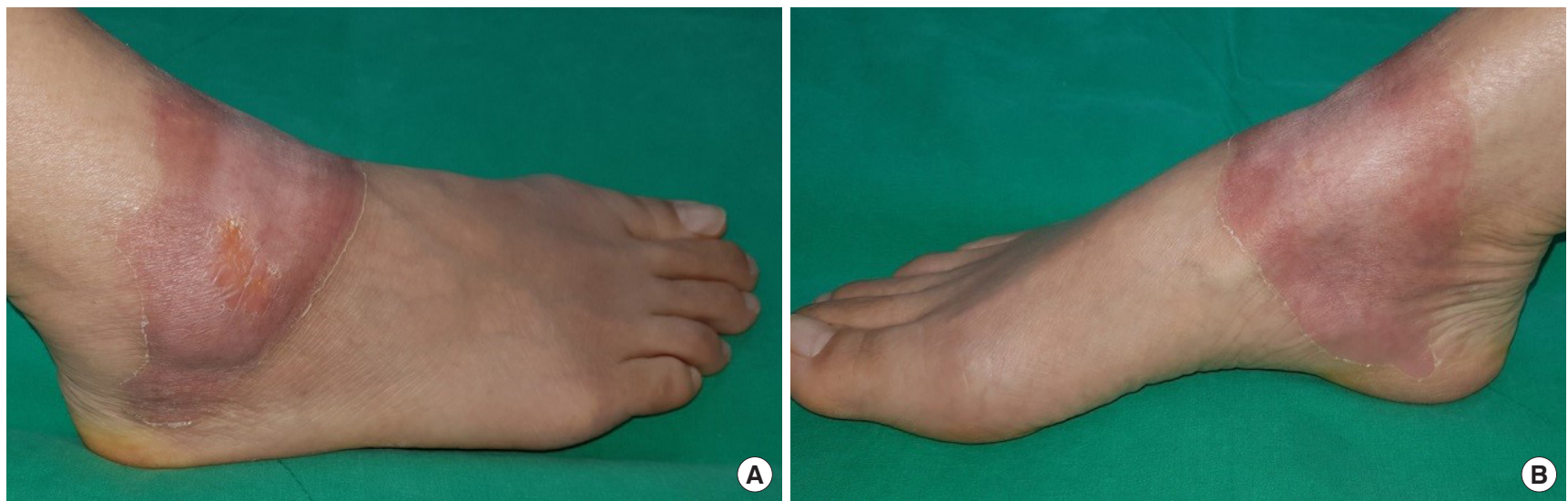

Fig. 4. Clinical photograph 3 weeks after injury. (A, B) Wound healing completed.

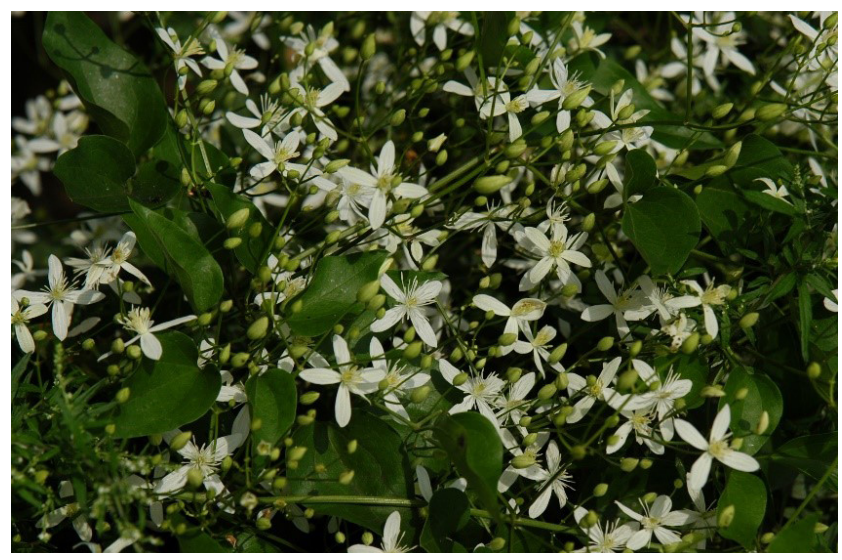

Fig. 5. Clematis terniflora is perennial vine. Stem is purple and flower is white. Reprinted with permission from Kim [1].

때문에 발생하는 아리는 통증에서 그 이름이 유래하였다고 한다[1].

미나리아재비과의 식물에서 나오는 아네모닌(anemonin) 성분이 생체 외에서 항염증 효과를 보인다[3]. 구체적으로 C. chinensis, $C$. mandshurica, C. microphylla, C. glycinoides, C. ligusticifolia, 그리고 C. brachiata는 염증이 있는 상황에서 항염증 효과를 보인다고 알려져 있다. 또한, C. mandshurica, C. montana, C. apiifolia는 항암 효과를 보 이고, 알칼로이드 $\alpha$ 와 $\beta, C$. parviloba에서 나오는 마그노플로린, $C$. tangutica로부터 추출되는 헤더라게니 당원질 등은 생체 외에서 항균 효과까지 보인다[3]. 이런 약리 효능들로 미나리아재비과의 식물들은 치질, 화상, 열상 및 찰과상 등의 치료에도 사용된다[2]. 또한, 관절염, 비염, 두통, 사마귀 등에도 효과가 좋다고 보고된다[4].

미나리아재비과의 풀들이 잘못 사용될 때 독성을 나타낼 수 있는 이유는 프로토아네모닌(protoanemonin)이라는 물질 때문이다[2]. 이 물질이 직접 피부와 점막에 닿게 되면, 황산염 가교(sulphate bridge) 를 파괴함으로써 표피 밑의 벌어짐(subepidermal disjunction) 그리고 수포 형성을 초래한다[4]. 식물이 신선할수록 그 독성은 더 커지게 된 다. 하지만 식물이 시들게 되면 프로토아네모닌은 이내 아네모닌으로
중합되게 되어, 독성을 잃게 되는데 건조하거나 끓인 상태에서도 마 찬가지로 무해하다고 볼수 있다[4].

이렇듯 식물을 이용한 민간요법의 부작용으로 보고된 사례로는 $\mathrm{Xu}$ 등[5]이 보고한 피부발진에 마늘을 도포하였다가 발생한 화학화 상의 증례, Ranunculus illyricus 도포로 기인한 접촉성 피부염 증례[6] 와 더불어 미나리아재비과 Ranunculus arvensis로 인한 화학화상 증 례[2] 등이 있다. 하지만 본 증례에서 보고하는 으아리풀에 의한 화학 화상 증례는 아직 국내뿐만 아니라 해외에서도 보고된 바가 없어 관 련 문헌고찰과 함께 보고하는 바이다.

민간요법은 오랜 시간에 걸쳐 경험적으로 내려오는 치료법이다. 이 는 자칫 오랜 기간을 지나며 그 안정성과 효능을 인정받았다고 확대 하여 해석할 여지가 있으나, 이는 명백히 옳지 못한 생각이다. 특히 민 간요법과 대체요법이 무분별하게 이루어지고 있는 한국에서는 이와 같이 옳지 못한 사용으로 인한 부작용에 더욱 주목해야 하며, 환자 들에게는 잘못된 정보를 토대로 한 민간요법보다는 작은 증상이 있 다고 하더라도 병원 치료를 장려하는 것이 옳을 것으로 생각된다.

\section{Conflict of interest}

No potential conflicts of interest relevant to this article are reported.

\section{References}

1. Kim JW. An illustrated treasury of Korean plants. Vol. 1. Synanthropophytes. Seoul: Nature \& Ecology; 2013.

2. Albayrak Y, Albayrak A, Melikoglu M, et al. Chemical burn caused by Ranunculus arvensis. Wounds 2011;23:E6-8.

3. Chawla R, Kumar S, Sharma A. The genus Clematis (Ranunculaceae): chemical and pharmacological perspectives. J Ethnopharmacol 2012;143:116-50.

4. Eskitascioglu T, Dogan F, Sahin G, et al. An extraordinary 
chemical burn injury cause: buttercup a report of five cases. Burns 2008;34:727-30.

5. Xu S, Heller M, Wu PA, et al. Chemical burn caused by topical application of garlic under occlusion. Dermatol Online J
2014;20:21261.

6. Polat M, Oztas P, Yalcin B, et al. Contact dermatitis due to Allivum sativum and Ranunculus illyricus: two cases. Contact Dermatitis 2007;57:279-80. 